(2) Open Access Full Text Article

\title{
Anticancer effect of dentatin and dentatin- hydroxypropyl- $\beta$-cyclodextrin complex on human colon cancer (HT-29) cell line
}

This article was published in the following Dove Press journal:

Drug Design, Development and Therapy

Number of times this article has been viewed

\begin{abstract}
Ashwaq Shakir
AL-Abboodi ${ }^{1,2}$

Abdullah Rasedee ${ }^{3}$

Ahmad Bustamam Abdul 1,4

Yun Hin Taufiq-Yap ${ }^{5}$

Wafaa Abd Alwahed Alkaby ${ }^{6}$

Mostafa Saddam Ghaji

Peter MWaziri ${ }^{1,8}$

Mothanna Sadiq Al-Qubaisi'

'MAKNA-UPM, Cancer Research Laboratory, Institute of Bioscience, University Putra Malaysia, Serdang,

Malaysia; ${ }^{2}$ Basic Science Branch, Faculty of Dentistry, University of Al-Qadisiyah, Al Diwaniyah, Iraq; ${ }^{3}$ Department of Veterinary Laboratory Diagnosis, Faculty of Veterinary Medicine, University Putra Malaysia, Serdang, Malaysia; ${ }^{4}$ Department of Biomedical Science, Faculty of Medicine and Health Science, University Putra Malaysia, Serdang, Malaysia; ${ }^{5}$ Department of Chemistry, Faculty of Science, University Putra Malaysia, Serdang, Malaysia; 'Department of Biomedical, Faculty of Biotechnology, University of AL-Qadisiyah, Al Diwaniyah, Iraq; ${ }^{7}$ Department of Anatomy and Histology, Faculty of Veterinary Medicine, University of Basrah, Basrah, Iraq; ${ }^{8}$ Department of Biochemistry, Kaduna State University, Main Campus, Kaduna, Nigeria
\end{abstract}

Correspondence: Ashwaq Shakir AL-Abboodi

Basic Science Branch, Faculty of Dentistry, University of AL-Qadisiyah, Al Diwaniyah, Qadisiyyah, Iraq

Tel +9647803589432

Email ashwaq.shaker@yahoo.com
Introduction: Dentatin (DEN) (5-methoxy-2, 2-dimethyl-10-(1, 1-dimethyl-2propenyl) dipyran-2-one), a natural compound present in the roots of Clausena excavata Burm $\mathrm{f}$, possesses pro-apoptotic and antiproliferative effects in various cancer cells. Because of its hydrophobicity, it is believed that its complexation with hydroxy- $\beta$-cyclodextrin (HP $\beta C D)$ will make it a potent inhibitor of cancer cell growth. In the current work, the molecular mechanisms of apoptosis induced by DEN and DEN-HP $\beta C D$ complex were demonstrated in human colon HT-29 cancer cells.

Materials and methods: After the human colon HT-29 cancer cells were treated with DEN and DEN-HPßCD complex, their effects on the expression of apoptotic-regulated gene markers in mitochondria-mediated apoptotic and death receptor pathways were detected by Western blot analysis and reverse transcription polymerase chain reaction. These markers included caspases-9, 3, and 8, cytochrome c, poly (ADP-ribose) polymerase, $\mathrm{p} 53$, p21, cyclin A as well as the Bcl-2 family of proteins.

Results: At 3, 6, 12, and $24 \mu \mathrm{g} / \mathrm{mL}$ exposure, DEN and DEN-HP $\beta C D$ complex significantly affected apoptosis in HT-29 cells through the down-regulation of Bcl-2 and cyclin A in turn, and up-regulation of Bax, p53, p21, cytochrome $\mathrm{c}$ at both protein and mRNA levels. DEN and DEN-HP $\beta C D$ complex also decreased cleaved poly (ADP-ribose) polymerase and induced caspases-3, -8 , and -9 .

Conclusion: Results of this study indicate that the apoptotic pathway caused by DEN and DEN-HP $\beta C D$ complex are mediated by the regulation of caspases and Bcl-2 families in human colon HT-29 cancer cells. The results also suggest that DEN-HP $\beta C D$ complex may have chemotherapeutic benefits for colon cancer patients.

Keywords: natural products, $\mathrm{HP} \beta C D$, apoptosis, pro-apoptotic proteins, anti-apoptotic proteins

\section{Introduction}

Colorectal cancer is the third most frequent cancer, representing $\sim 10 \%$ of all cancer cases. In 2012, >1.4 million colon cancer cases ${ }^{1}$ with 700,000 deaths ${ }^{2}$ were recorded worldwide. In the USA and Europe, colon cancers are more common in men than women. Colon cancer can be inherited, with $>85 \%$ of colon cancer patients having family history of the disease. ${ }^{2}$

Dentatin (DEN), a very hydrophobic compound, is naturally occurring in Clausena excavata. ${ }^{3-6} \mathrm{DEN}$ was shown to have inhibitory effects on breast, ${ }^{6}$ prostate $^{7}$ and liver cancer cells. ${ }^{8}$ In many human cancer cells, DEN induced apoptosis by up-regulating pro-apoptotic proteins, for example, Bax and $\mathrm{Bak}^{6}$ and apoptotic protease-activating factor 1 , activating caspases, ${ }^{7}$ and down-regulating antiapoptotic, for example, Bcl-X1, 
poly (ADP-ribose) polymerase (PARP) and increasing leakage of cytochrome $\mathrm{c}$ from the mitochondria. Furthermore, DEN-mediated apoptosis was also shown to be associated with increase in tumor necrosis factor-related apoptosisinducing ligand in cancer cells..$^{7-10}$

In a previous study, we demonstrated that DEN has proapoptotic properties. ${ }^{11}$ DEN was also shown to have antimammary gland cancer effects in rats. ${ }^{12}$ The anticancer effects of DEN are quite selective, it being innocuous to normal cells. ${ }^{7-9}$ DEN in a complex with hydroxy- $\beta$-cyclodextrin (HP $\beta C D)$ (DEN-HP $\beta C D)$ also caused growth inhibition of MDA-MB-231, LNCaP, and HGT cell lines. ${ }^{11}$ The cancer inhibitory effect of DEN-HP $\beta C D$ occurs through the induction of apoptosis, particularly by overexpressing the Bax proteins. ${ }^{9}$ In cancer cells, DEN directly acts on the mitochondria to release cytochrome c. ${ }^{6,7}$ The incorporation of lipophilic compounds into the HP $\beta C D$ cavity does not only improve their water solubility while in complexation but also enhances therapeutic effects. ${ }^{13}$ Although it was shown that DEN either free or incorporated in HP $\beta C D$ induces cancer cell death via apoptosis, the molecular mechanisms associated with their anticancer activities is not clear. In our current work, we investigated the anticancer molecular mechanism of DEN and DEN-HPßCD on the HT-29 cancer cells.

\section{Materials and methods}

\section{Materials}

The HP $\beta C D$ (purity $\geq 98 \%$ ) used in this investigation was procured from Sigma Aldrich (Taufkirchen, Germany). All the chemical materials and reagents used were analytical grade and ultrapure water was used during all the experimental steps.

\section{Cell culture}

Human colon cancer (HT-29) cells obtained from American Type Culture Collection (Manassas, VA, USA) were maintained in DMEM. The media were supplemented with $10 \%$ fetal bovine serum, $1 \%$ amphotericin $\mathrm{B}$ and $1 \%$ penicillinstreptomycin. The cells were maintained in a humidified incubator maintained at $37^{\circ} \mathrm{C}$ and under $5 \% \mathrm{CO}_{2}$ and examined frequently under an inverted microscope (Micros, Salzburg, Austria).

\section{Preparation of the inclusion complex}

DEN in HP $\beta C D$ solution at 1:1 molar ratio was prepared by dissolving $0.3264 \mathrm{~g} \mathrm{DEN}$ in $5 \mathrm{~mL}$ chloroform and mixing with $1.4 \mathrm{~g} \mathrm{HP} \beta C D$ in $20 \mathrm{~mL}$ of ultrapure water. The mixture was stirred at room temperature for 72 hours and filtered using $0.45 \mu \mathrm{m}$ filter paper. The solution was frozen at $-80^{\circ} \mathrm{C}$ and subsequently freeze-dried for 24 hours at $-55^{\circ} \mathrm{C}$. Freezedrying method was employed to convert the complex from the liquid to solid state.

\section{Western blotting analysis}

The HT-29 cells were centrifuged at $1,000 \times g$ for 10 minutes and the cell pellet collected and lysed with lysis buffer (50 mM Tris- $\mathrm{HCl} \mathrm{pH} 8.0,120 \mathrm{mM} \mathrm{NaCl}, 0.5 \%$ NP-40, $1 \mathrm{mM}$ phenylmethylsulfonyl fluoride). Protein $40 \mu \mathrm{g}$ was loaded onto $10 \%$ sodium dodecyl sulfate-polyacrylamide gels and electrophoresed. After electrophoresis, the protein was transferred to a polyvinylidene difluoride (PVDF) membrane (Bio-Rad; Hercules, CA, USA) and the membrane blocked with $5 \%$ non-fat dry milk in tris-buffered saline-Tween buffer 7 (0.12 M Tris-base, $1.5 \mathrm{M} \mathrm{NaCl}, 0.1 \%$ Tween 20$)$ at room temperature for 2 hours. The membrane was then incubated with primary mouse antibody either against $\beta$-actin $(1: 2,000)$, caspase-3 $(1: 2,000)$, cytochrome c $(1: 2,000)$, Bax $(1: 2,000)$, Bcl-2 (1:2,000), p12 (1:2,000), p53 (1:2,000) or PARP (1:2,000) (Genomax Technologies Sdn Bhd., Selangor, Malaysia) overnight at $4{ }^{\circ} \mathrm{C}$ followed by incubation with horseradish peroxidase-conjugated secondary antibody (goat anti-mouse 1:1,000) for 1 hour at room temperature. Proteinantibody complexes were detected by chemiluminescence (ECL System) (WesternBrightTM, Advansta, Menlo Park, CA, USA) before autoradiography (ChemiDoc MP imaging System/Bio-Rad, Kuala Lumpur, Malaysia).

\section{Reverse transcription-polymerase chain reaction (RT-PCR) \\ RNA extraction}

The extraction was done using the Aurum Total RNA Mini kit (Bio-Rad). After treatments, the cells were transferred to a $2 \mathrm{~mL}$ microcentrifuge tube and centrifuged at $20,000 \times \mathrm{g}$ for 2 minutes. The supernatant was discarded and $350 \mu \mathrm{L}$ lysis solution added to each tube followed by $350 \mu \mathrm{L} 70 \%$ ethanol, and mixed thoroughly to obtain the homogenized lysate. The RNA binding column was inserted into a $2 \mathrm{~mL}$ wash tube and $700 \mu \mathrm{L}$ homogenized lysate pipetted into the RNA binding column that was then centrifuged at $20,000 \times g$ for 30 seconds. Then, $700 \mu \mathrm{L}$ low stringency wash solution was added to the RNA binding column and the column centrifuged at $20,000 \times g$ for 30 seconds. The ribonuclease-free deoxyribonuclease 1 was then added with mixing followed by $700 \mu \mathrm{L}$ high stringency wash solution. After centrifugation at $20,000 \times g$ for 30 seconds, the wash solution was discarded and replaced with $700 \mu \mathrm{L}$ of fresh low stringency wash solution. The column was recentrifuged at $20,000 \times g$ for 1 minute before discarding 
the wash solution. Then, the RNA was left for 1 minute before centrifuging at $20,000 \times g$ for 2 minutes to obtain the RNA. Nanodrop Bio Spectrometer was employed to quantify the RNA. All centrifugations were performed in the Eppendorf 5424 microcentrifuge (Eppendorf, Hamburg, Germany).

\section{cDNA synthesis}

First-strand complementary DNA (cDNA) was synthesized from 600 ng RNA using the iScript cDNA Synthesis kit (Bio-Rad). The cDNA synthesis was performed in the Mastercycler Gradient (Eppendorf AG, Eppendorf, Hamburg, Germany). The total reaction volume (cDNA $20 \mu \mathrm{L}$ reaction) comprised of: $5 \times$ iScript reaction mix $(4 \mu \mathrm{L})$, iScript reverse transcriptase $(1 \mu \mathrm{L})$, nuclease-free water $(13 \mu \mathrm{L})$ and RNA template $(2 \mu \mathrm{L})$. The reaction mixture was incubated for 5 minutes at $25^{\circ} \mathrm{C}$, then for 30 minutes at $42^{\circ} \mathrm{C}$. The reaction mixture was finally heated at $85^{\circ} \mathrm{C}$ for 5 minutes and the synthesized cDNA stored at $-20^{\circ} \mathrm{C}$.

\section{The cDNA PCR amplification}

cDNA PCR amplification was carried out using a thermal cycler (C1000 Touch, Bio-Rad), and a My Taq Mix kit (Bioline, Taunton, MA, USA) was used for amplification. All the primers sequences used in RT-PCR were analyzed and components of the PCR reaction are described in Tables 1 and 2.

\section{PCR condition}

\section{$\beta$-actin, p53 and Bax}

The PCR cycling conditions for $\beta$-actin, p53, Bax were; amplication at $95^{\circ} \mathrm{C}$ for 1 minute, denaturation for 30 cycles at $95^{\circ} \mathrm{C}$ for 15 seconds, annealing at $60^{\circ} \mathrm{C}$ for 15 seconds, and primer extension at $72^{\circ} \mathrm{C}$ for 10 seconds, and with a final extension at $72^{\circ} \mathrm{C}$ for 7 minutes.

Table I Primer sequences of primers used in RT-PCR

\begin{tabular}{lll}
\hline Primers & Forward primer & Reverse primer \\
\hline Caspase-3 & TCA CAG CAA AAG & CGT CAA AGG AAA \\
& GAG CAG TTT & AGG ACT CAA \\
Caspase-9 & CCA GAG ATT CGC & GAG CAC CGA CAT \\
& AAA CCA GAG G & CAC CAA ATC C \\
Caspase-8 & GAA AAG CAA ACC & CCA AGT GTG TTC \\
& TCG GGG ATA C & CAT TCC TGT C \\
p53 & TGT GGA GTA TTT & GAA CAT GAG TTT \\
& GGA TGA CA & TTT ATG GC \\
Cyclin A & GTC ACC ACA TAC & AAG TTT TCC TCT \\
& TAT GGA CAT G & CAG CAC TGA C \\
Bax & CAC CAG CTC TGA & GCG AGG CGG \\
& GCA GAT & TGA GCA CTC \\
$\beta$-actin & TCA CCC TGA AGT & CCA TCT CTT GCT \\
& ACC CCA TC & GCA AGT CC \\
\hline
\end{tabular}

Abbreviation: RT-PCR, reverse transcription-polymerase chain reaction.
Table 2 The components of PCR reaction

\begin{tabular}{ll}
\hline Components & Volume $(\mu \mathrm{L})$ \\
\hline My Taq Mix, $2 \times$ & 25 \\
Forward primer & 1 \\
Reverse primer & 1 \\
cDNA template & 4 \\
Water $\left(\mathrm{ddH}_{2} \mathrm{O}\right)$ & 19 \\
Total volume & 50 \\
\hline
\end{tabular}

Abbreviations: cDNA, complimentary DNA; PCR, polymerase chain reaction.

\section{Caspases- 9 and -8}

The PCR cycling conditions for caspases-9 and -8 were; amplification at $95^{\circ} \mathrm{C}$ for 1 minute, denaturation for 30 cycles at $95^{\circ} \mathrm{C}$ for 15 seconds, annealing at $56.6^{\circ} \mathrm{C}$ for 15 seconds, primer extension at $72^{\circ} \mathrm{C}$ for 10 seconds, and final extension at $72^{\circ} \mathrm{C}$ for 7 minutes.

\section{Cyclin A}

The PCR cycling conditions for cyclin A were; amplication at $95^{\circ} \mathrm{C}$ for 1 minute, denaturation for 30 cycles at $95^{\circ} \mathrm{C}$ for 15 seconds, annealing at $52^{\circ} \mathrm{C}$ for 15 seconds, and primer extension at $72^{\circ} \mathrm{C}$ for 10 seconds, and final extension at $72^{\circ} \mathrm{C}$ for 7 minutes.

\section{Agarose gel electrophoresis preparation}

Agarose gel has been used to separate RNA. Agarose gel electrophoresis $(1.5 \%)$ was prepared by dispensing $1.5 \mathrm{~g}$ agarose powder in a $200 \mathrm{~mL}$ conical flask containing $100 \mathrm{~mL}$ running buffer, which was prepared by mixing $2 \mathrm{~mL}$ stock TAE (50×) (a buffer solution containing a mixture of Tris base, acetic acid and EDTA) with $98 \mathrm{~mL}$ distilled water. The agarose gel was placed in the microwave to melt. Then, $1 \mu \mathrm{L} 10 \mathrm{mg} / \mathrm{mL}$ ethidium bromide was added to the melted agarose gel and the gel poured into the casting tray to solidify. TAE buffer was poured into the chamber to completely submerge the gel.

\section{RNA samples preparation}

Each sample was mixed with loading buffer and $1 \mu \mathrm{L}$ loading dye was mixed with $5 \mu \mathrm{L}$ sample. The samples were loaded into the wells and the gel electrophoresed for 60 minutes at 110 Volts. The bands were then visualized under ultraviolet light (Bio-Rad gel documentation system/Bio-Rad).

\section{Results Western blot analysis Caspase-3}

When the HT-29 cell line was exposed to $3 \mu \mathrm{g} / \mathrm{mL}$ of DEN and DEN-HP $\beta C D$ for 24 hours, caspase-3 protein expression 


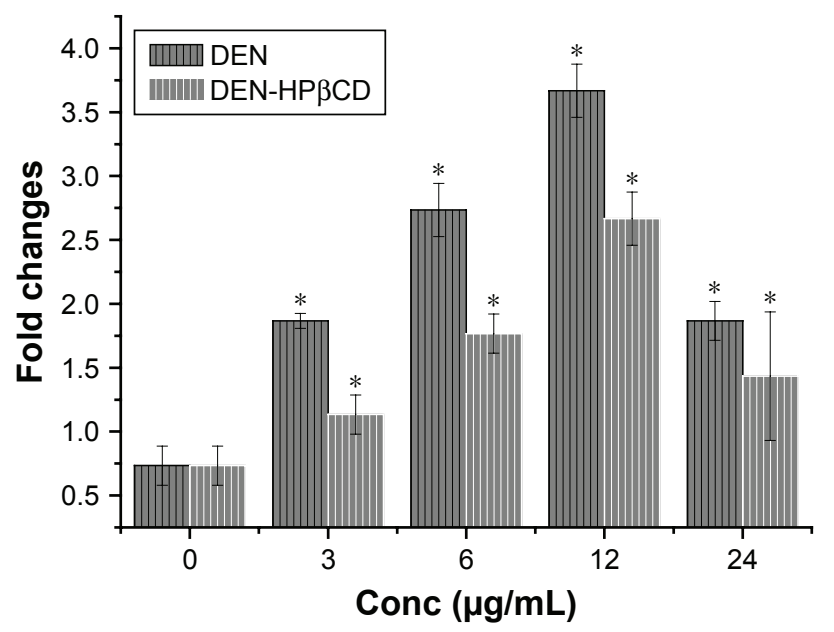

Figure I Expression of caspase-3 protein in HT-29 cells treated with DEN and DEN-HP $\beta C D$-treated for 24 hours.

Notes: Caspase-3 protein expression peaked at treatment concentration of $12 \mu \mathrm{g} / \mathrm{mL}$. Values are ratio $\pm \mathrm{SD}$. *Significantly $(p<0.05)$ different from control $(0$ $\mu \mathrm{g} / \mathrm{mL}$ ). The data were analysed by one-way analysis of variance.

Abbreviations: Conc, concentration; DEN, dentatin; HP $\beta C D$, hydroxypropyl- $\beta$ cyclodextrin; HT-29, human colon cancer.

increased by 1.86 -fold and 1.13-fold compared with that in untreated cells, respectively. At $6 \mu \mathrm{g} / \mathrm{mL}$, the expression was markedly increased by 2.73 - and 1.76-fold while the highest increase was obtained when the treatments were given at $12 \mu \mathrm{g} / \mathrm{mL}$, at 3.66- and 2.66-fold, respectively. With $24 \mu \mathrm{g} / \mathrm{mL}$ treatment concentration, the increase in the caspase-3 protein expression was slightly lower than at $12 \mu \mathrm{g} / \mathrm{mL}$
(Figure 1). The results show that caspase-3 protein expression was induced by DEN and DEN- HP $\beta C D$ in a dose-dependent manner, with free DEN producing greater effect.

\section{Cytochrome c}

Figure 2 shows expression of cytochrome c protein in colon cancer HT-29 cells treated for 24 hours with DEN and DEN-HP $\beta C D$ complex. There were gradual increases in the cytochrome c expression with increase in dose. The greatest effect was seen with $24 \mu \mathrm{g} / \mathrm{mL}$ of DEN and DEN-HP $\beta C D$ complex treatments that increased the cytochrome $\mathrm{c}$ protein expression by 1.79- and 1.29-fold higher than the controls, respectively (Figure 3 ).

\section{p53}

The expressions of p53 protein in DEN- and DENHP $\beta C D$-treated HT-29 cells are shown in Figure 4. The HT-29 cells showed marked increase in p53 protein expression in a dose-dependent manner. The highest p53 protein expression was with $24 \mu \mathrm{g} / \mathrm{mL}$ DEN and DEN-HP $\beta C D$ complex treatments, reaching $\sim 238 \%$ and $213 \%$ that of the control cells, respectively.

\section{$\mathrm{Bcl}-2$}

Bcl-2 protein expression in HT-29 cells decreased gradually with increase in DEN and DEN-HP $\beta$ CD complex

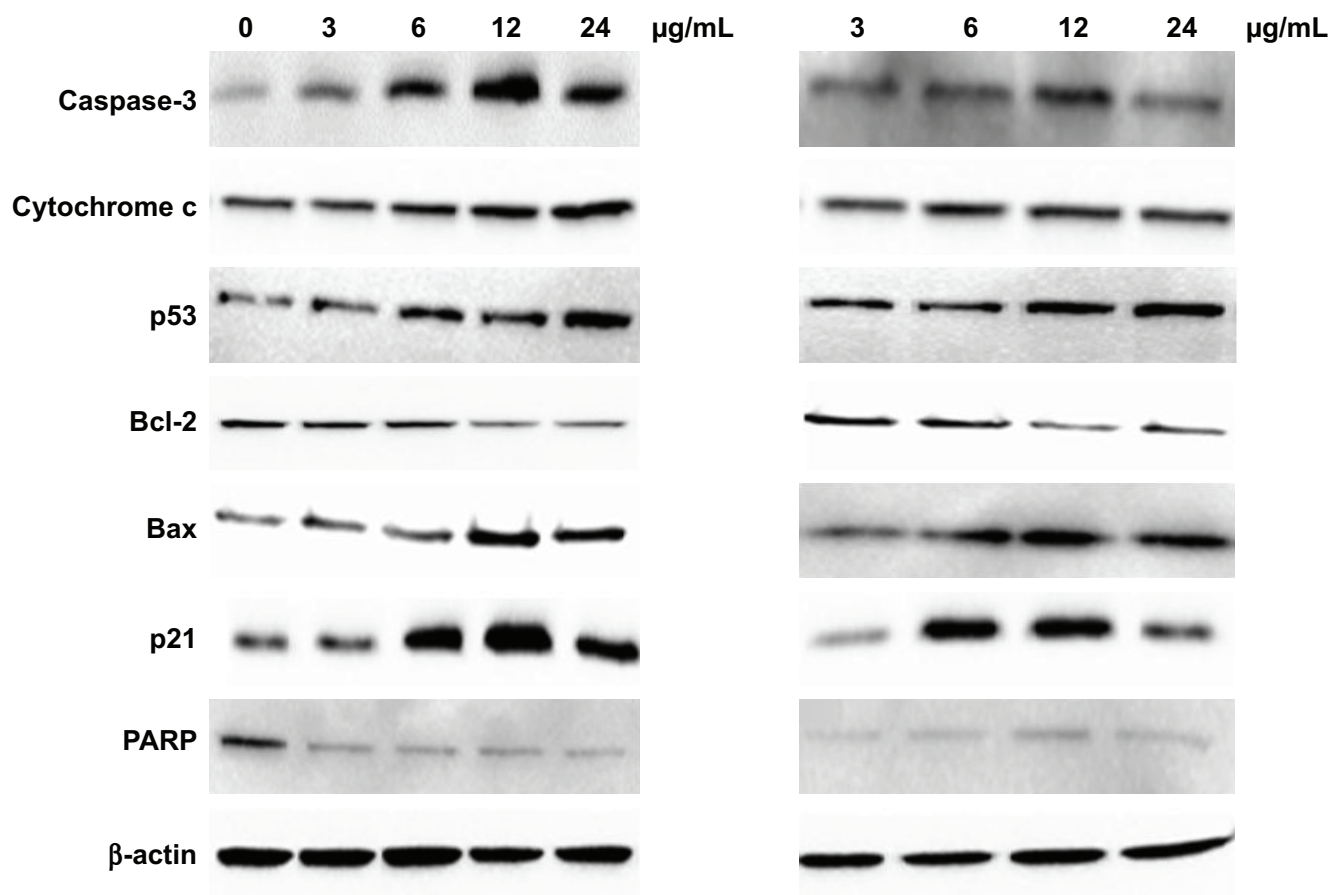

Figure 2 Expression of pro- and anti-apoptotic proteins, P2I and PARP in HT-29 cells shown by Western blot analysis.

Note: DEN and DEN-HP $\beta C D$ treatment increased caspase-3, cytochrome c, p53, Bax, and p2I and reduced Bcl-2 and PARP protein expressions. Abbreviations: DEN, dentatin; HP $\beta C D$, hydroxypropyl- $\beta$-cyclodextrin; PARP, poly (ADP-ribose) polymerase. 


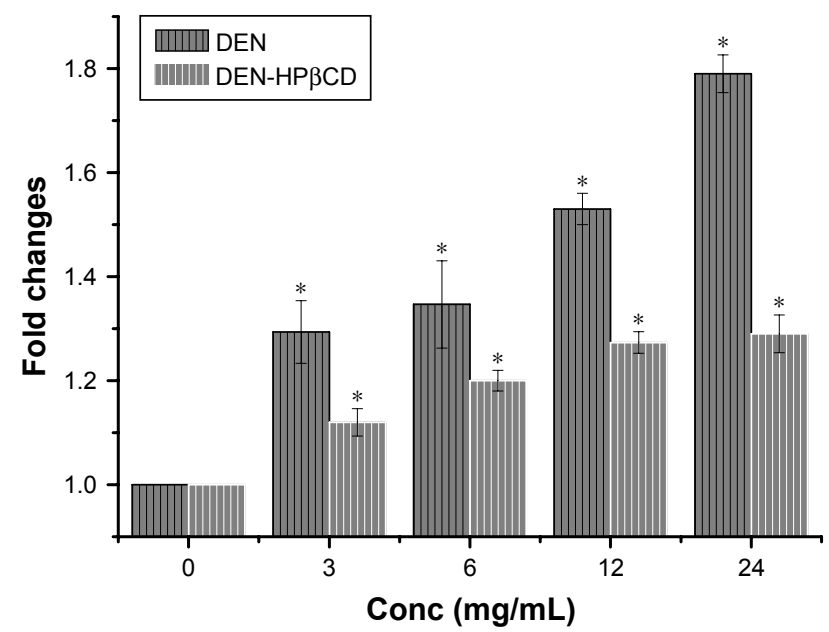

Figure 3 Expression of cytochrome c protein in HT-29 cells treated with DEN and DEN-HPBCD for 24 hours.

Notes: Cytochrome c protein expression peaked at treatment concentration of $24 \mu \mathrm{g} / \mathrm{mL}$. Values are ratio $\pm \mathrm{SD}$. *Significantly $(p<0.05)$ different from control $(0 \mu \mathrm{g} / \mathrm{mL})$. The data were analysed by one-way analysis of variance.

Abbreviations: Conc, concentration; DEN, dentatin; HP $\beta C D$, hydroxypropyl- $\beta$ cyclodextrin; HT-29, human colon cancer.

concentrations reaching the lowest value at treatment concentrations of 12 and $24 \mu \mathrm{g} / \mathrm{mL}$ (Figure 5).

\section{Bax}

Pro-apoptotic Bax protein expression in HT-29 cells treated with DEN and DEN-HP $\beta$ CD complex is shown in Figure 2. The expressions of the protein increased with increase in treatment concentration. The highest expression was at 12 $\mu \mathrm{g} / \mathrm{mL}$ of DEN and DEN-HP $\beta C D$ complex, reaching $\sim 180 \%$ and $170 \%$ of the control values, respectively (Figure 6).

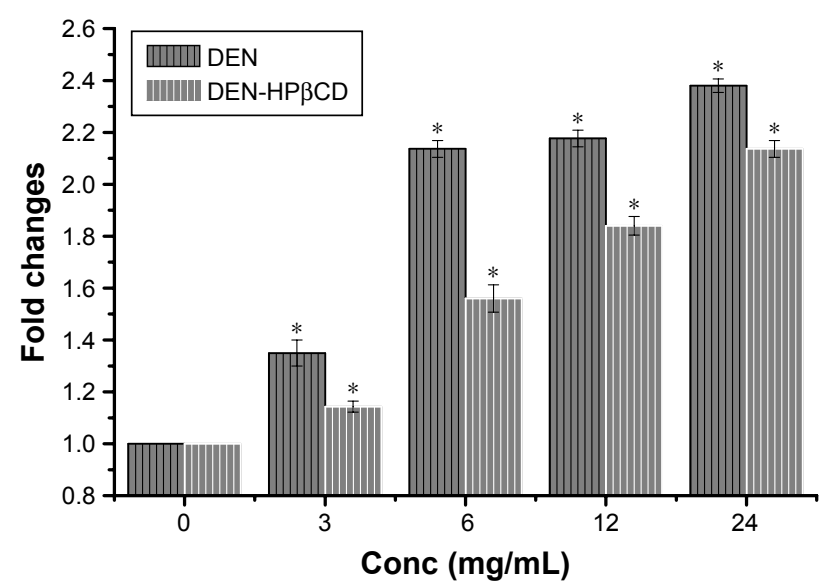

Figure 4 Expression of $\mathrm{p} 53$ protein in HT-29 cells treated with DEN and DEN-HPßCD for 24 hours.

Notes: Expression of $\mathrm{p} 53$ protein peaked at treatment concentration of $24 \mu \mathrm{g} / \mathrm{mL}$. Values are ratio \pm SD. *Significantly $(p<0.05)$ different from control $(0 \mu \mathrm{g} / \mathrm{mL})$. The data were analysed by one-way analysis of variance.

Abbreviations: Conc, concentration; DEN, dentatin; HP $\beta C D$, hydroxypropyl- $\beta$ cyclodextrin; HT-29, human colon cancer.

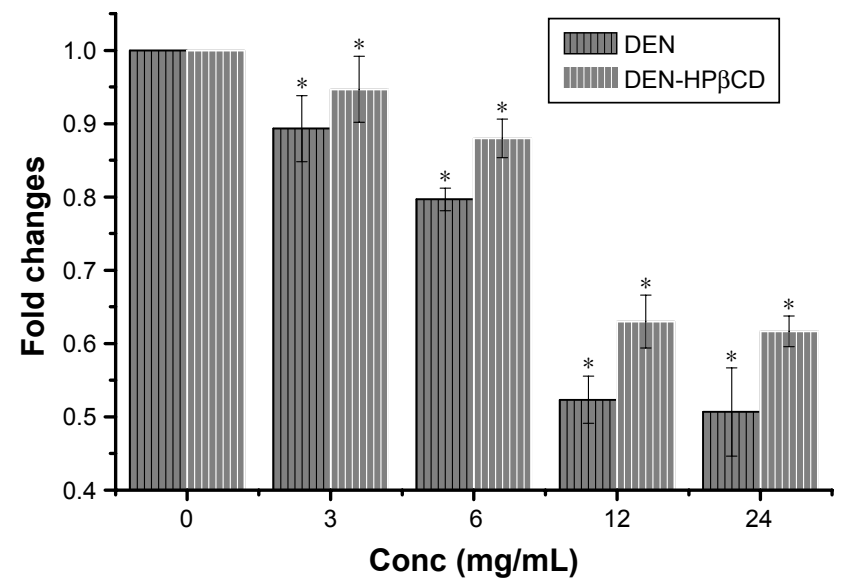

Figure 5 Expression of $\mathrm{Bcl}-2$ protein in HT-29 cells treated with DEN and DEN-HPßCD for 24 hours.

Notes: Expressions of Bcl-2 protein were lowest with 12 and $24 \mu \mathrm{g} / \mathrm{mL}$ treatment concentrations. Values are ratio \pm SD. *Significantly $(p<0.05)$ different from control $(0 \mu \mathrm{g} / \mathrm{mL})$. The data were analysed by one-way analysis of variance.

Abbreviations: Conc, concentration; DEN, dentatin; HP $\beta C D$, hydroxypropyl- $\beta$ cyclodextrin; HT-29, human colon cancer.

\section{P21}

Treatment with $3 \mu \mathrm{g} / \mathrm{mL}$ DEN and DEN-HP $\beta C D$ did not cause significant $(p>0.05)$ up-regulation in $\mathrm{p} 21$ protein expression of HT-29 cells (Figure 7). Shape increases in $\mathrm{p} 21$ expression began with $6 \mu \mathrm{g} / \mathrm{mL}$ DEN and DENHP $\beta C D$ complex treatment by $2.4-$ and 2.7 -fold, respectively (Figure 7). The p21 expressions peaked with $12 \mu \mathrm{g} / \mathrm{mL}$ DEN and DEN-HP $\beta C D$ complex treatment, and the expression decreased with treatment concentration of $24 \mu \mathrm{g} / \mathrm{mL}$.

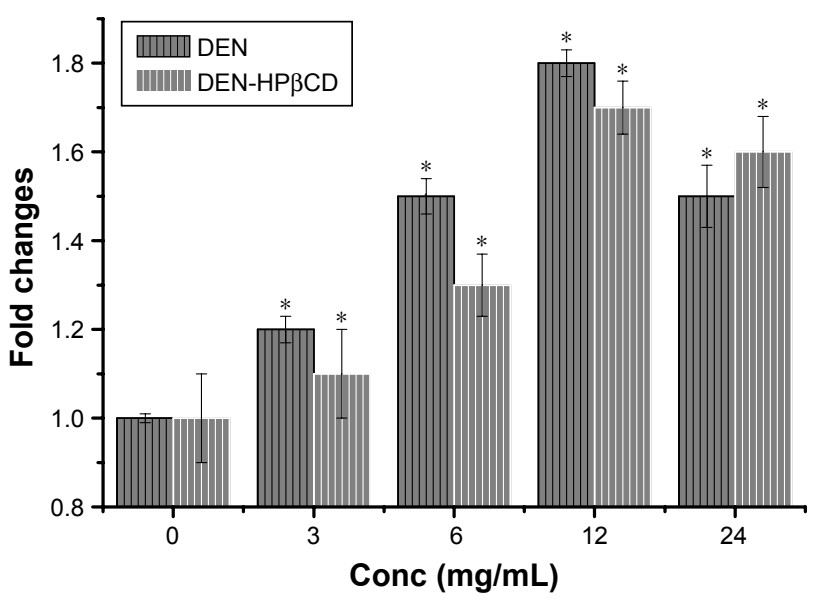

Figure 6 Expression of Bax protein in HT-29 cells treated with DEN and DEN-HPßCD for 24 hours.

Notes: Expressions of Bax protein were highest at $12 \mu \mathrm{g} / \mathrm{mL}$ treatment concentrations. Values are ratio \pm SD. *Significantly $(p<0.05)$ different from control $(0 \mu \mathrm{g} / \mathrm{mL})$. The data were analysed by one-way analysis of variance.

Abbreviations: Conc, concentration; DEN, dentatin; HP $\beta C D$, hydroxypropyl- $\beta$ cyclodextrin; HT-29, human colon cancer. 


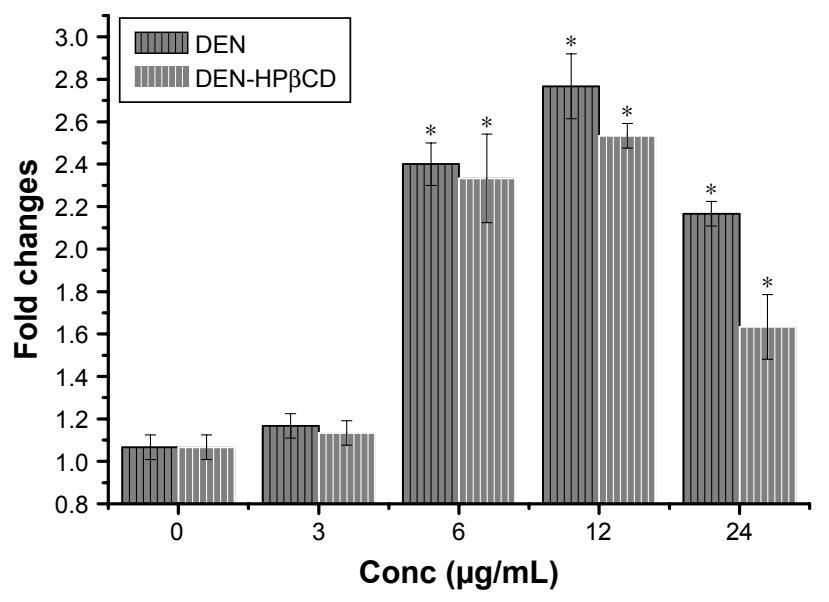

Figure 7 Expression of $\mathrm{p} 2 \mathrm{I}$ protein in HT-29 cells treated with DEN and DEN-HP $\beta C D$ for 24 hours.

Notes: Expression of $\mathrm{p} 2 \mathrm{I}$ protein peaks at $12 \mu \mathrm{g} / \mathrm{mL}$ treatment concentration. Values are ratio \pm SD. $*$ Significantly $(p<0.05)$ different from control $(0 \mu \mathrm{g} / \mathrm{mL})$. The data were analysed by one-way analysis of variance.

Abbreviations: Conc, concentration; DEN, dentatin; HP $\beta C D$, hydroxypropyl- $\beta$ cyclodextrin; HT-29, human colon cancer.

\section{Poly (ADP-ribose) polymerase}

Expression of PARP protein decreased, compared with control, with DEN and DEN-HP $\beta C D$ complex treatments at all concentrations showing both compounds suppressed PARP expressions (Figure 8).

\section{Reverse transcription-polymerase chain reaction}

RT-PCR was used to determine the effect of DEN and DEN-HP $\beta C D$ complex on certain apoptosis- and cell cycleassociated genes in HT-29 cells. RT-PCR analysis of mRNA

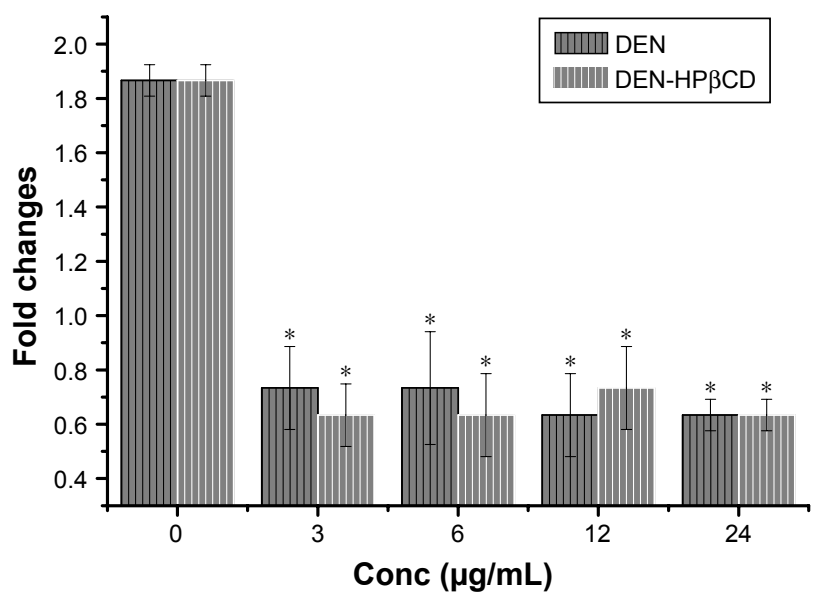

Figure 8 Expression of PARP protein in HT-29 cells treated with DEN and DEN-HPßCD for 24 hours.

Notes: Expression of PARP was downregulated by treatment with all concentrations of DEN and DEN-HPBCD complex. Values are ratio \pm SD. *Significantly $(p<0.05)$ different from control $(0 \mu \mathrm{g} / \mathrm{mL})$. The data were analysed by one-way analysis of variance.

Abbreviations: Conc, concentration; DEN, dentatin; HP $\beta C D$, hydroxypropyl- $\beta$ cyclodextrin ; HT-29, human colon cancer; PARP, poly (ADP-ribose) polymerase. expression for samples was estimated by the thickness of bands.

\section{Caspase-3}

Figure 9 shows the gene expression caspase-3 in HT-29 cells treated with DEN and DEN-HP $\beta C D$ complex. The expression of caspase-3 gene in the HT-29 was up-regulated as a result of treatments. The highest expression in the DENtreated cells was with treatment concentration of $12 \mu \mathrm{g} / \mathrm{mL}$ (Figure 9). DEN produced greater effect on HT-29 caspase-3 gene expression than DEN-HP $\beta C D$ complex.

\section{Caspase-9}

Caspase-9 gene expression increased in the DEN- and DEN-HP $\beta C D$ complex-treated HT-29 cells (Figure 10). The results show that caspase- 9 decreased when the DEN

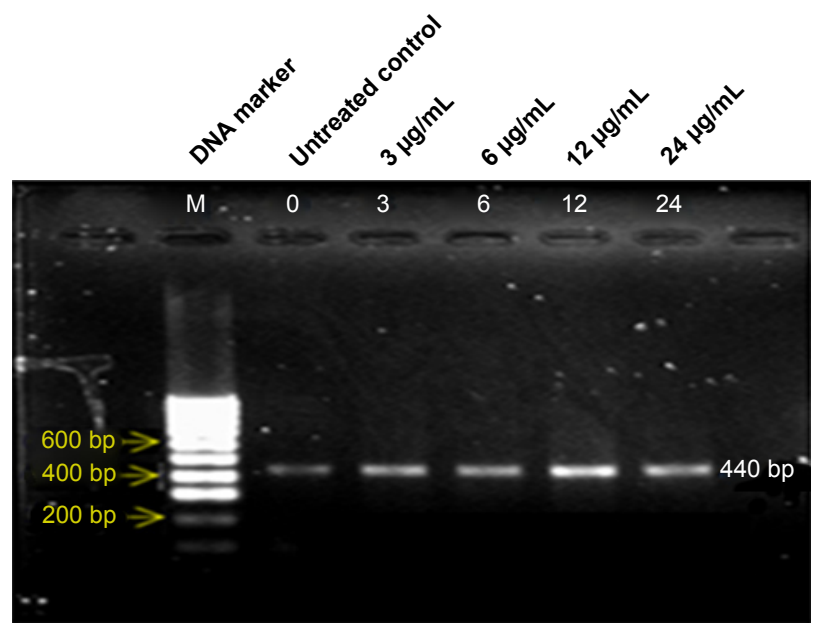

Dentatin $(\mu \mathrm{g} / \mathrm{mL})$

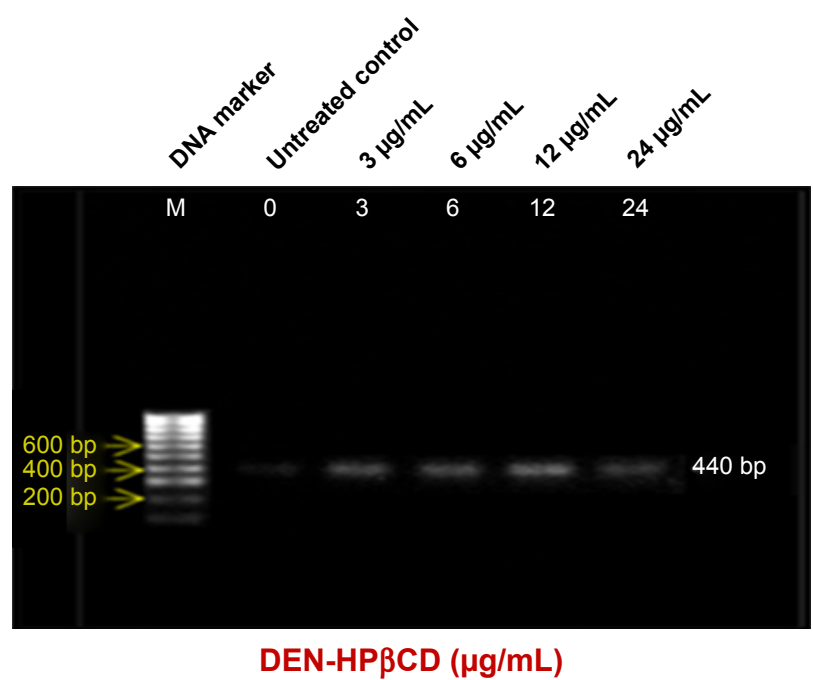

Figure 9 RT-PCR analysis for caspase-3 mRNA expression in HT-29 cells treated with DEN and DEN-HP $\beta C D$ complex for 24 hours.

Notes: $M=$ marker. The size of caspase- 3 gene is $440 \mathrm{bp}$.

Abbreviations: DEN, dentatin; HP $\beta C D$, hydroxypropyl- $\beta$-cyclodextrin; HT-29, human colon cancer; RT-PCR, reverse transcription-polymerase chain reaction. 


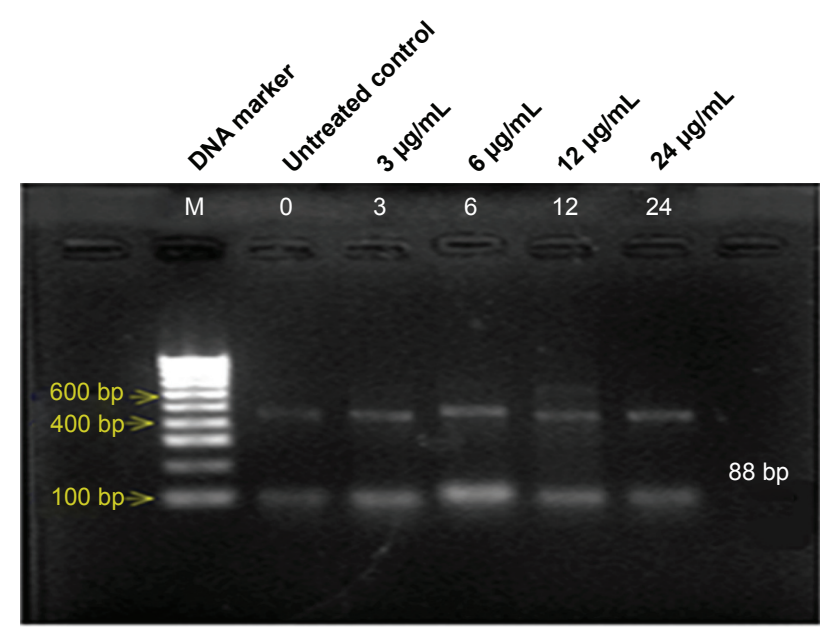

Dentatin $(\mu \mathrm{g} / \mathrm{mL})$

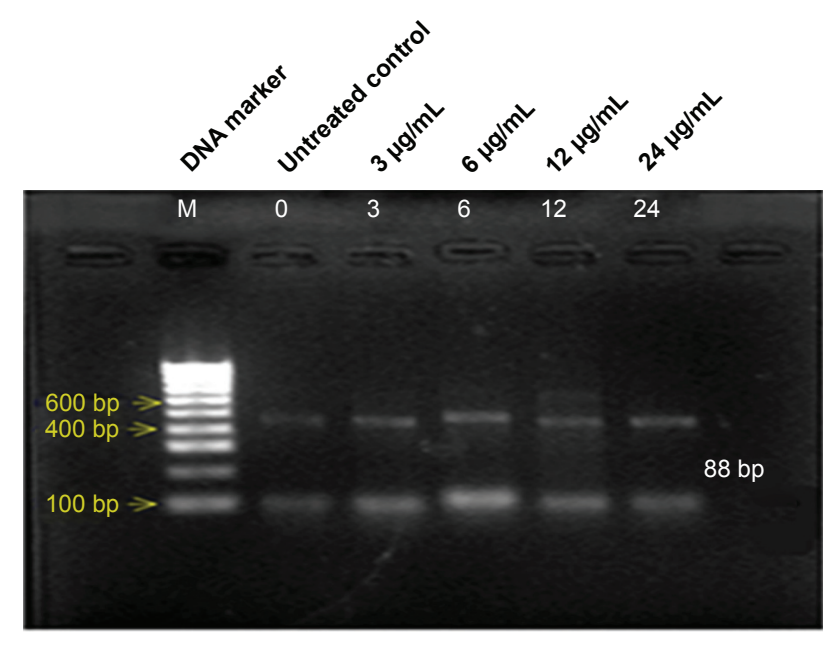

DEN-HP $\beta C D(\mu \mathrm{g} / \mathrm{mL})$

Figure 10 RT-PCR analysis for caspase- 9 mRNA expression in HT-29 cells treated with DEN and DEN-HP $\beta C D$ complex for 24 hours.

Notes: $M=$ marker. The size of caspase- 9 gene is $88 \mathrm{bp}$. The upper series of bands belong to another gene.

Abbreviations: DEN, dentatin; HPßCD, hydroxypropyl- $\beta$-cyclodextrin; HT-29, human colon cancer; RT-PCR, reverse transcription-polymerase chain reaction.

concentration exceeded $6 \mu \mathrm{g} / \mathrm{mL}$. Clear increase in caspase-9 expression in DEN-HP $\beta C D$-treated cells began at $12 \mu \mathrm{g} / \mathrm{mL}$ treatment dose.

\section{Caspase-8}

Caspase- 8 gene expressions in HT-29 cells treated with DEN and DEN-HP $\beta C D$ complex are shown in Figure 11. The highest gene expressions were at 6 and $12 \mu \mathrm{g} / \mathrm{mL}$ of both compounds. The caspase- 8 gene expression decreased when the treatment concentration increased to $24 \mu \mathrm{g} / \mathrm{mL}$, for both compounds.

\section{Bax}

Bax gene expression increased slightly after 24 hours exposure to $3 \mu \mathrm{g} / \mathrm{mL}$ of DEN and DEN-HP $\beta C D$ compared

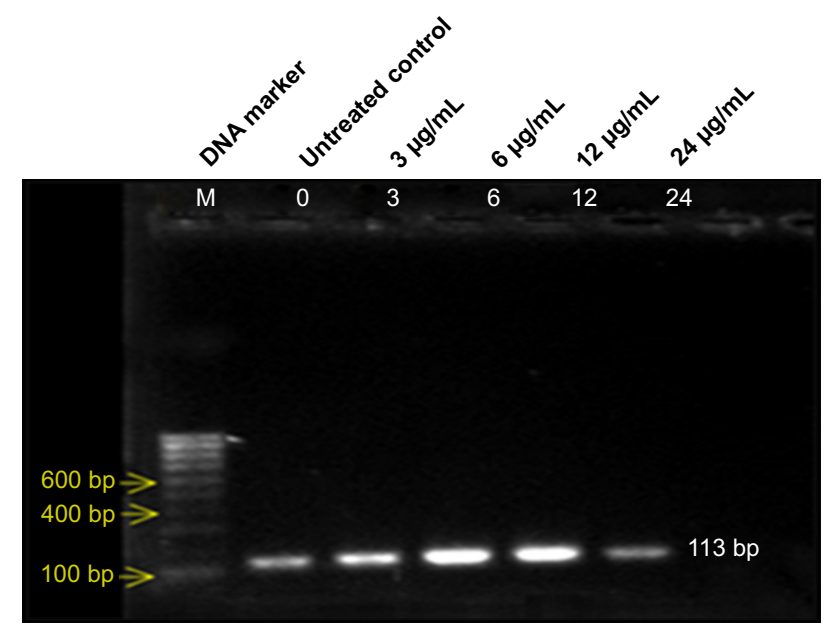

Dentatin $(\mu \mathrm{g} / \mathrm{mL})$

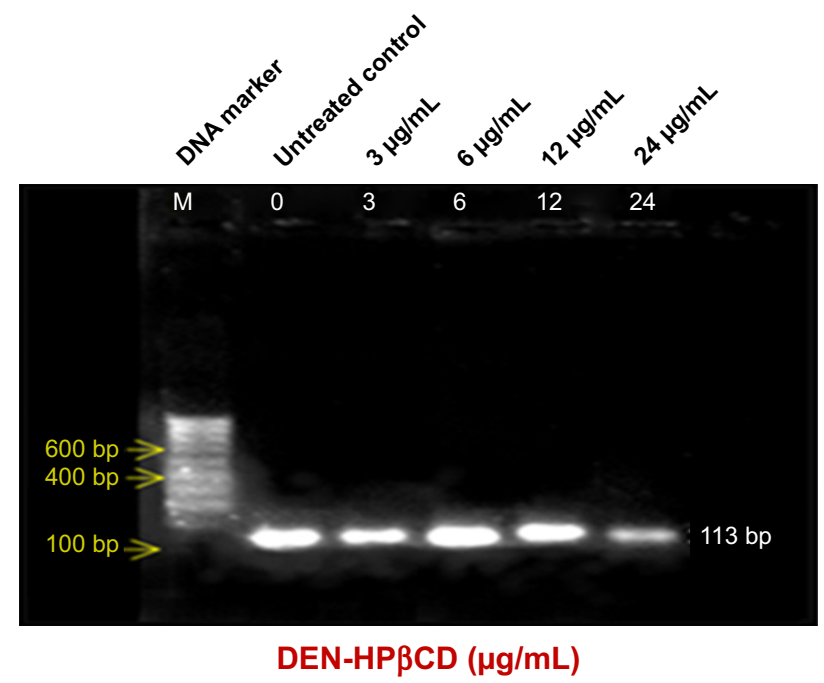

Figure I I RT-PCR analysis for caspase-8 mRNA expression in HT-29 cells treated with DEN and DEN-HPBCD complex for 24 hours.

Notes: $M=$ marker. The size of caspase- 8 gene is 113 bp.

Abbreviations: DEN, dentatin; HP $\beta C D$, hydroxypropyl- $\beta$-cyclodextrin; HT-29, human colon cancer; RT-PCR, reverse transcription-polymerase chain reaction.

with control (Figure 12). The expression level continued to increase gradually with increase in treatment concentrations. The Bax gene expression was greatest at treatment dose of $12 \mu \mathrm{g} / \mathrm{mL}$.

\section{p53}

Figure 13 shows the p53 gene expressions in HT-29 cells after treatment with DEN and DEN-HP $\beta C D$. The expression levels of p53 gene in the HT-29 cells increased with increase in treatment concentrations.

\section{Cyclin A}

After exposure of the HT-29 cells to DEN and DEN-HP $\beta C D$ for 24 hours, the cyclin A gene decreased with increasing treatment concentrations (Figure 14). The untreated HT-29 


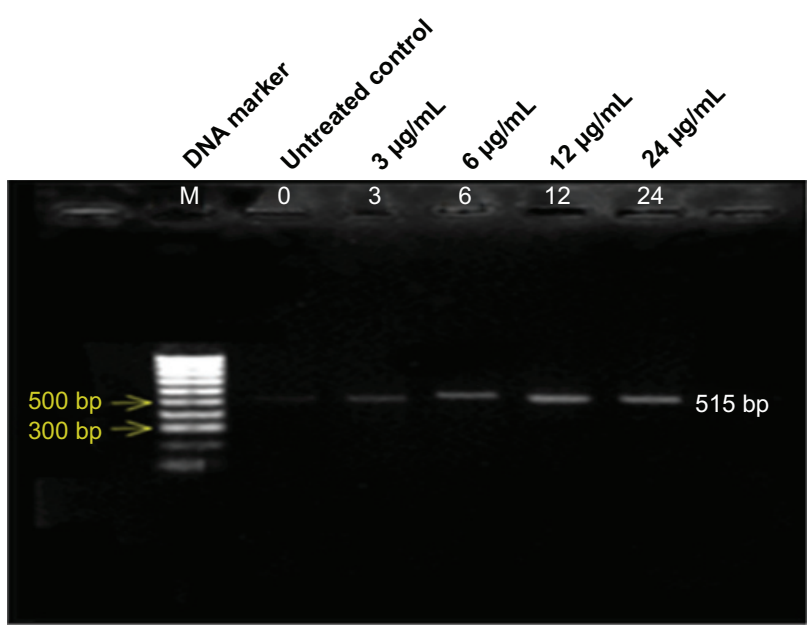

Dentatin $(\mu \mathrm{g} / \mathrm{mL})$

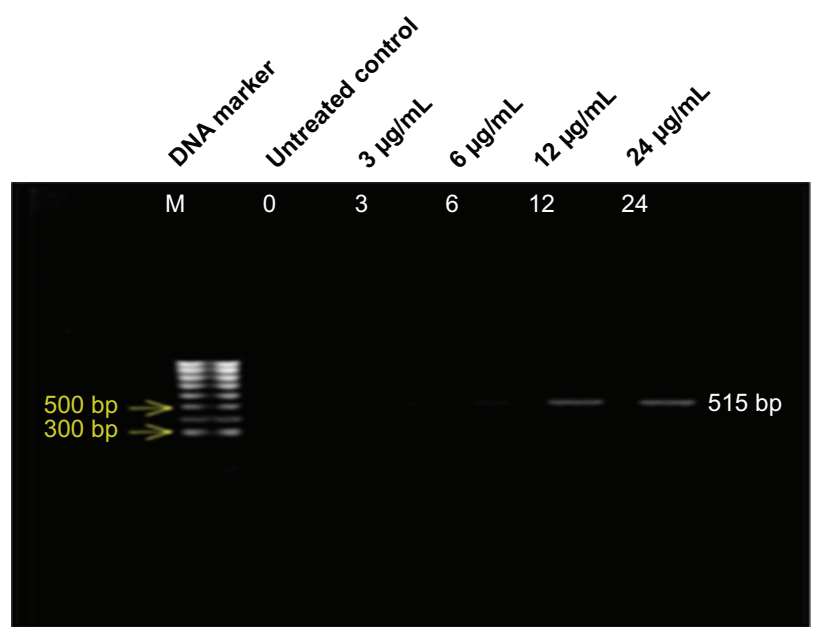

DEN-HPßCD $(\mu \mathrm{g} / \mathrm{mL})$

Figure 12 RT-PCR analysis for Bax mRNA expression in HT-29 cells treated with $D E N$ and DEN-HP $\beta C D$ complex for 24 hours.

Notes: $M=$ marker. The size of Bax gene is 515 bp.

Abbreviations: DEN, dentatin; HP $\beta C D$, hydroxypropyl- $\beta$-cyclodextrin; HT-29, human colon cancer; RT-PCR, reverse transcription-polymerase chain reaction.

cells showed the highest cyclin A gene expression. The DEN and DEN-HP $\beta C D$ treatment downregulated HT-29 cell cyclin A gene.

\section{$\beta$-actin}

The $\beta$-actin expression in the HT-29 cells is shown in Figure 15. The concentrations of DEN and DEN-HP $\beta C D$ complex did not seem to affect the expression of $\beta$-actin gene in the treated cells. The gene was equally expressed at all treatment concentrations.

\section{Discussion}

Cells exposed to stress respond by showing unique morphological and biochemical changes. ${ }^{14}$ Some cells die through apoptosis, autophagy, or necrosis as a result of stress. ${ }^{15}$

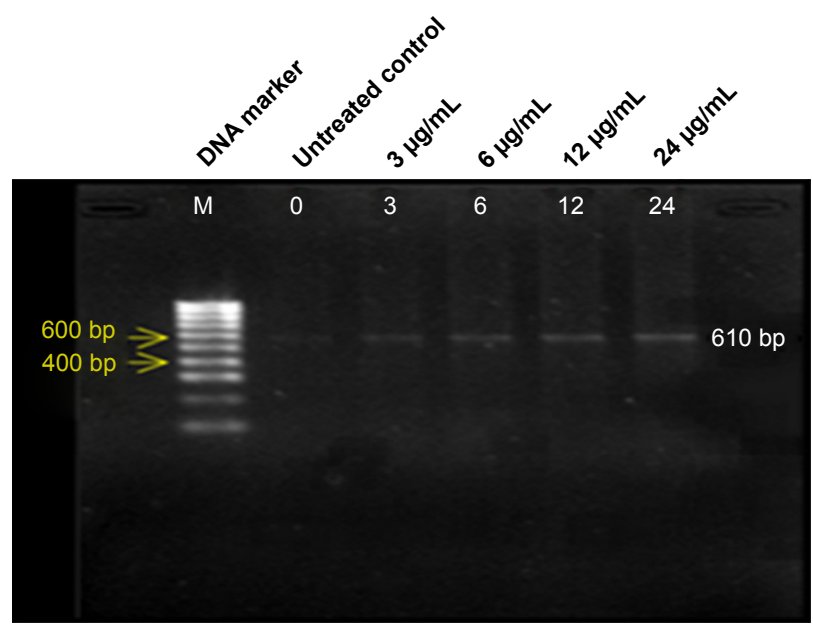

Dentatin $(\mu \mathrm{g} / \mathrm{mL})$

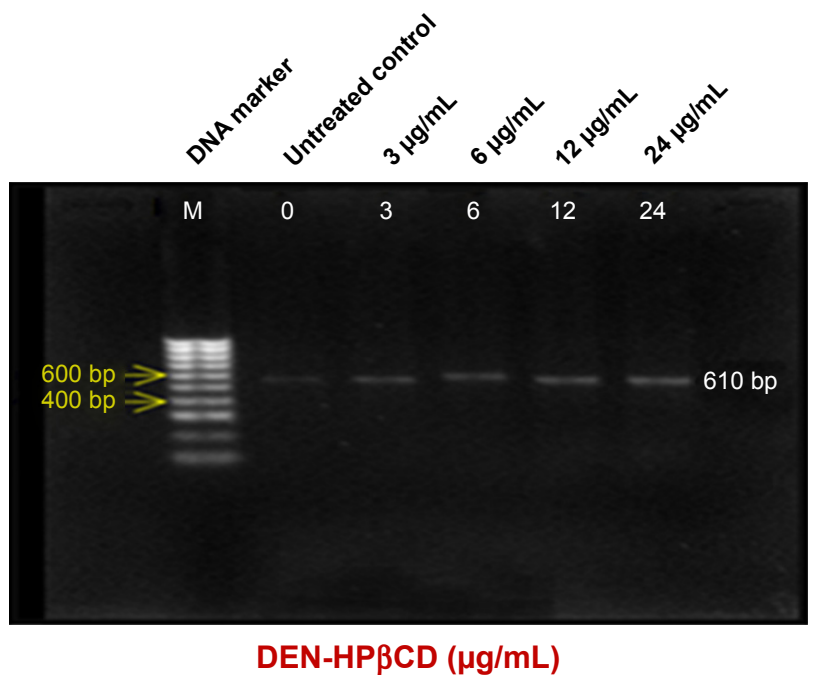

Figure 13 RT-PCR analysis for $\mathrm{p} 53$ mRNA expression in HT-29 cells treated with $D E N$ and DEN-HPBCD complex for 24 hours.

Notes: $M=$ marker. The size of $p 53$ gene is $610 \mathrm{bp}$.

Abbreviations: DEN, dentatin; HP $\beta C D$, hydroxypropyl- $\beta$-cyclodextrin; HT-29, human colon cancer; RT-PCR, reverse transcription-polymerase chain reaction.

Whether the traumatized cells die depends on the extent of type of injury and cell genotype. ${ }^{16}$ Both apoptosis and autophagy are parts of the genetically encoded programmed cell suicidal death with specific features. ${ }^{17}$ Such inherent programs act as repair mechanisms to dispose of effete and damaged cells without affecting homeostasis, the immune system or tissue maintenance. ${ }^{14}$

Our study attributed the effect of DEN on the HT-29 cells to apoptosis and cell cycle arrest. DEN, either free or in complex with HP $\beta C D$ caused the reduction in Bcl-2 while increasing Bax expression in a dose-dependent manner. This effect can be attributed to the potential of the drug to affect p53 expression. p53 is a multifunctional protein involved in activation of the transcription factors that regulate apoptotic genes expression. ${ }^{14}$ With increase in p53 in the HT-29 cells, 


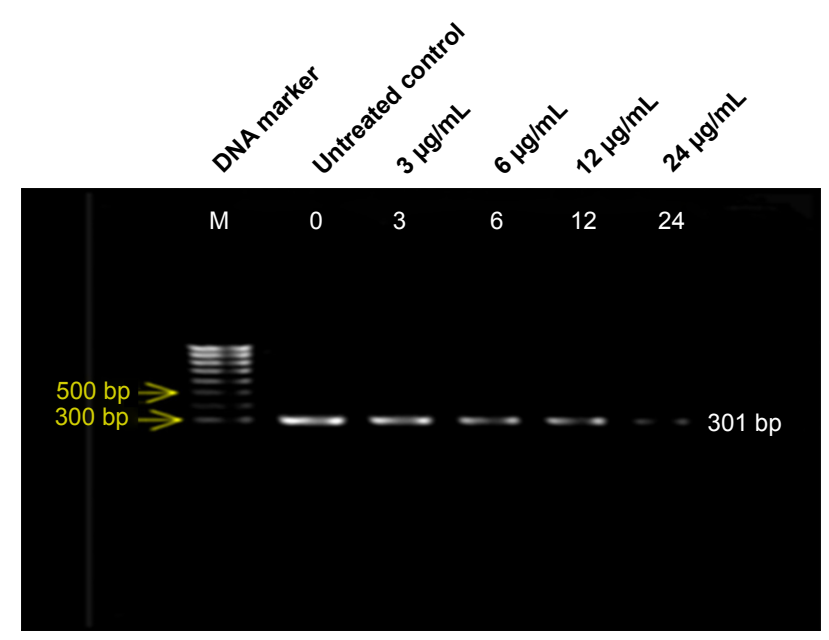

Dentatin $(\mu \mathrm{g} / \mathrm{mL})$

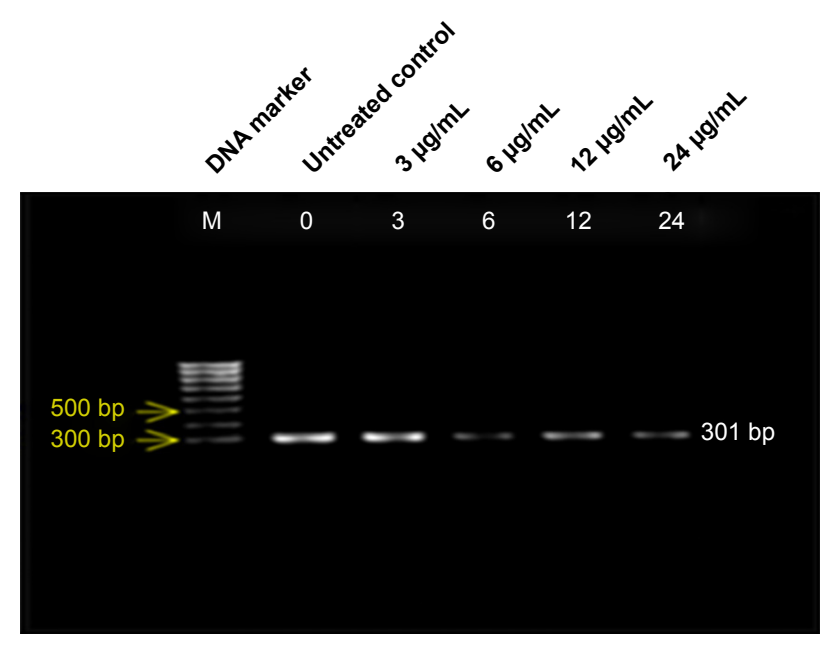

DEN-HP $\beta C D(\mu \mathrm{g} / \mathrm{mL})$

Figure I4 RT-PCR analysis for cyclin A mRNA expression in HT-29 cells treated with DEN and DEN-HP $\beta C D$ complex for 24 hours.

Notes: $M=$ marker. The size of cyclin A gene is 301 .

Abbreviations: DEN, dentatin; HP $\beta C D$, hydroxypropyl- $\beta$-cyclodextrin; HT-29, human colon cancer; RT-PCR, reverse transcription-polymerase chain reaction.

DEN inhibits proliferation of the cancer cells which contributes to its antitumor effect. DEN also induced an increase in $\mathrm{p} 21$ protein expression in a dose-dependent manner. This also impacts on the apoptotic pathway through the induction of p53 gene and protein expression.

The G2 phase is highly dominated by 2 types of cyclindependent kinase; cdk1 and 2 enzymes whose action is inhibited by $\mathrm{p} 21$. DEN, free or as DEN-HP $\beta C D$ also decreases cyclin A which is responsible for the regulation of cell cycle progression. The effects of DEN on the cycle regulators results in G2 phase arrest in the treated HT-29 cells and this effect increases with increase in treatment concentration.

The results also showed that both DEN and DEN-HP $\beta C D$ complex increased cytochrome c expression in HT-29 cells. The effect of DEN on cytochrome c was greater by

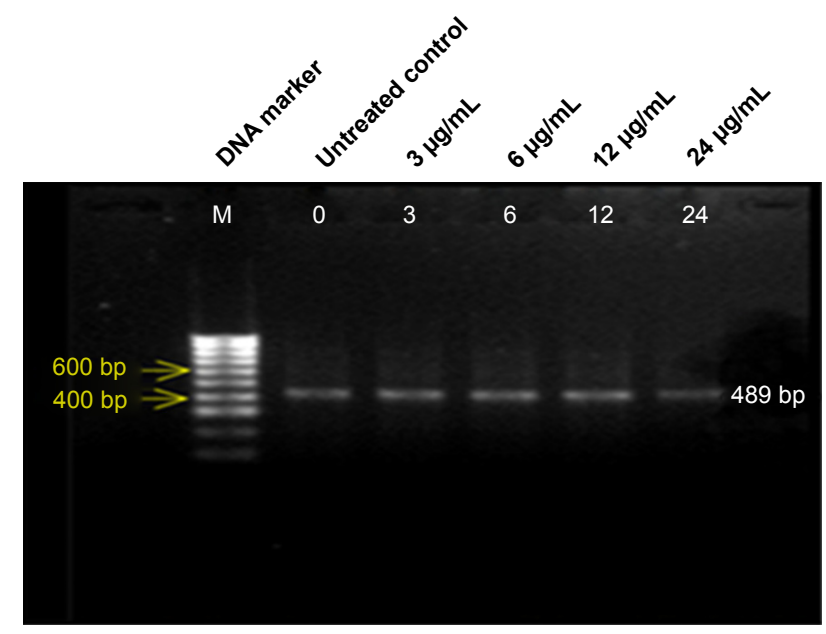

Dentatin $(\mu \mathrm{g} / \mathrm{mL})$

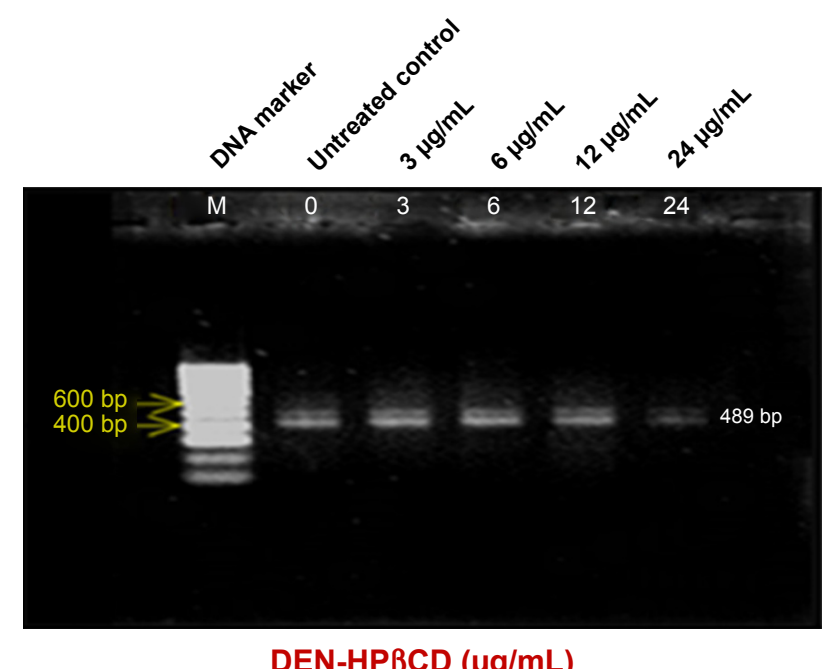

Figure I5 RT-PCR analysis for $\beta$-actin mRNA expression in HT-29 cells treated with DEN and DEN-HP $\beta C D$ complex for 24 hours.

Notes: $\mathrm{M}=$ marker. The size of $\beta$-actin gene is $489 \mathrm{bp}$.

Abbreviations: DEN, dentatin; HP $\beta C D$, hydroxypropyl- $\beta$-cyclodextrin; HT-29, human colon cancer; RT-PCR, reverse transcription-polymerase chain reaction.

DEN than DEN-HP $\beta C D$. This may be mediated through the up-regulation of Bax and down-regulation of Bcl-2 factors regulating the mitochondrial membrane potential. The cytochrome c plays a majority role like caspase-3, -9 , and -8 in inducing apoptosis of the HT-29 cells. ${ }^{18}$ The DEN and DEN-HP $\beta C D$ complex at high doses had greater tendency to induce necrosis rather than apoptosis. This effect is postulated to be the cause of decrease in caspase activities with treatment of $24 \mu \mathrm{g} / \mathrm{mL}$ of the compounds. ${ }^{19}$

PARP acts as a safeguard against development of single-stranded DNA breaks when the cells are exposed to stressful stimuli.

When DNA damage occurs, PARP binds to the DNA to begin repair. ${ }^{20}$ This is the basis of cell survival in tissues. DEN and DEN-HP $\beta C D$ caused the down-regulation of PARP in 
the HT-29 cells. This prevents damaged HT-29 cells from recovering. By down-regulation of PARP, DEN and DENHP $\beta C D$ encourage damaged HT-29 cells to undergo apoptosis and this prevents the proliferation of the cancer cells.

\section{Statistical analysis}

All the experiments were conducted in triplicate, and the results are reported in terms of mean \pm SD. Statistical analysis was accomplished by using SPSS throughout the experiments. The analysis of variance was carried out using the analysis of variance technique, and a value of $p<0.05$ was deemed to be of statistical significance.

\section{Conclusion}

The study shows that DEN and DEN-HP $\beta C D$ complex are toxic to the HT-29 cells. The anti-HT-29 cell effects of DEN and DEN-HPBCD are through the induction of apoptosis and cell cycle arrest. The results show that DEN-HP $\beta C D$, in particular has potential to be developed into an anticancer drug carrier system.

\section{Acknowledgments}

This research was supported by science fund research grant (02-01-04-sf1210), Ministry of Science, Technology and Innovation, Malaysia. The author (ASA-A) is grateful to the University of Al-Qadisiyah, Ministry of Higher Education and Scientific Research, Iraq.

\section{Author contributions}

All authors contributed toward data analysis, drafting and revising the paper and agree to be accountable for all aspects of the work.

\section{Disclosure}

The authors report no conflicts of interest in this work.

\section{References}

1. Grant WB. Role of solar UVB irradiance and smoking in cancer as inferred from cancer incidence rates by occupation in Nordic countries. Dermatoendocrinol. 2012;4(2):203-211.

2. Ågesen TH, Sveen A, Merok MA, et al. ColoGuideEx: a robust gene classifier specific for stage II colorectal cancer prognosis. Gut. 2012; 61(11):1560-1567.

3. Arbab IA, Abdul AB, Abdelwahab SI. Clausena excavata Burm. $f$. (Rutaceae): A review of its traditional uses, pharmacological and phytochemical properties [Doctoral thesis]. Serdang, Malaysia: University Putra Malaysia; 2015.
4. Cheng SS, Chang HT, Lin CY, et al. Insecticidal activities of leaf and twig essential oils from Clausena excavata against Aedes aegypti and Aedes albopictus larvae. Pest Manag Sci. 2009;65(3):339-343.

5. Arbab IA, Abdul AB, Aspollah M, Abdelwahab SI, Ibrahim MY, Ali Z. A review of traditional uses, phytochemical and pharmacological aspects of selected members of Clausena genus (Rutaceae). $J$ Med Plants Res. 2012;6(38):5107-5118.

6. Arbab IA, Abdul AB, Sukari MA, et al. Dentatin isolated from Clausena excavata induces apoptosis in MCF-7 cells through the intrinsic pathway with involvement of NF- $\mathrm{KB}$ signalling and $\mathrm{G} 0 / \mathrm{G} 1$ cell cycle arrest: a bioassay-guided approach. J Ethnopharmacol. 2013;145(1): 343-354.

7. Arbab IA, Looi CY, Abdul AB, et al. Dentatin induces apoptosis in prostate cancer cells via Bcl-2, Bcl-xL, Survivin downregulation, caspase-9,-3/7 activation, and NF- $\kappa \mathrm{B}$ inhibition. Evid Based Complement Alternat Med. 2012;2012:856029.

8. Andas AR, Abdul AB, Rahman HS, et al. Dentatin from clausena excavata induces apoptosis in HEPG2 cells via mitochondrial mediated signaling. Asian Pac J Cancer Prev. 2015;16(10):4311-4316.

9. Ashwaq AS, Al-Qubaisi MS, Rasedee A, Abdul AB, Taufiq-Yap YH, Yeap SK. Inducing G2/M Cell Cycle Arrest and Apoptosis through Generation Reactive Oxygen Species (ROS)-Mediated Mitochondria Pathway in HT-29 Cells by Dentatin (DEN) and Dentatin Incorporated in Hydroxypropyl- $\beta$-Cyclodextrin (DEN-HP $\beta C D)$. Int J Mol Sci. 2016; 17(10):E1653.

10. Kawaii S, Tomono Y, Ogawa K, et al. Antiproliferative effect of isopentenylated coumarins on several cancer cell lines. Anticancer Res. 2000; 21(3B): 1905-1911.

11. Ashwaq A-AS, Rasedee A, Abdul AB, Taufiq-Yap YH, Al-Qubaisi MS, Eid EE. Characterization, drug release profile and cytotoxicity of Dentatin-Hydroxypropyl- $\beta$-Cyclodextrin complex. J Incl Phenom Macrocycl Chem. 2017;87(1-2):167-178.

12. Arbab IA, Sani NA, Ibrahim MY, Abdalla B. Dentatin from Clausena excavata induces apoptosis and reduces the tumors size of $\mathrm{La}-7$ induced mammary carcinogenesis in sprague dawley rats. Int $J$ Adv Multidiscip Res. 2015;2:67-73.

13. Davis ME, Brewster ME. Cyclodextrin-based pharmaceutics: past, present and future. Nat Rev Drug Discov. 2004;3(12):1023-1035.

14. Ouyang L, Shi Z, Zhao S, et al. Programmed cell death pathways in cancer: a review of apoptosis, autophagy and programmed necrosis. Cell Prolif. 2012;45(6):487-498.

15. Tan ML, Ooi JP, Ismail N, Moad AI, Muhammad TS. Programmed cell death pathways and current antitumor targets. Pharm Res. 2009; 26(7):1547-1560.

16. Santos S, Silva AM, Matos M, Monteiro SM, Álvaro AR. Copper induced apoptosis in Caco-2 and Hep-G2 cells: expression of caspases 3, 8 and 9, AIF and p53. Comp Biochem Physiol C Toxicol Pharmacol. 2016;185:138-146.

17. Bialik S, Zalckvar E, Ber Y, Rubinstein AD, Kimchi A. Systems biology analysis of programmed cell death. Trends Biochem Sci. 2010;35(10): $556-564$.

18. Ghobrial IM, Witzig TE, Adjei AA. Targeting apoptosis pathways in cancer therapy. CA Cancer J Clin. 2005;55(3):178-194.

19. Ladilov Y, Appukuttan A. Role of soluble adenylyl cyclase in cell death and growth. Biochim Biophys Acta. 2014;1842(12 Pt B): 2646-2655.

20. Morales J, Li L, Fattah FJ, et al. Review of poly (ADP-ribose) polymerase (PARP) mechanisms of action and rationale for targeting in cancer and other diseases. Crit Rev Eukaryot Gene Expr. 2014; 24(1):15-28. 


\section{Publish your work in this journal}

Drug Design, Development and Therapy is an international, peerreviewed open-access journal that spans the spectrum of drug design and development through to clinical applications. Clinical outcomes, patient safety, and programs for the development and effective, safe, and sustained use of medicines are the features of the journal, which has also been accepted for indexing on PubMed Central. The manuscript management system is completely online and includes a very quick and fair peer-review system, which is all easy to use. Visit http://www.dovepress.com/testimonials.php to read real quotes from published authors.

Submit your manuscript here: http://www.dovepress.com/drug-design-development-and-therapy-journal 